\title{
TRENDS OF THE PROCES OF MODERNIZATION OF FARMS MANAGED BY YOUNG FARMERS
}

\author{
Zbigniew Brodzinski ${ }^{1}$, phd. habilitated, prof. UWM \\ ${ }^{1}$ Warmia and Mazury University in Olsztyn, Poland
}

\begin{abstract}
The paper presents an analysis of the farms manager by young farmers. The research was carried out in 2018 in the Warminsko-Mazurskie Voivodeship and included two groups, including 32 young farmers and 48 farmers aged 40 or over. Participants of the study were farmers who cooperate with the Warmian-Masurian Agricultural Advisory Center and run development farms, with a commodity character of production.

The aim of the research was to find the answer to the question whether young farmers using preferences under the Common Agricultural Policy are more willing than other farmers to modernize the farms which they manage. In the group of young farmers covered by the survey, the average area of farms managed by them was 31.47 ha, while in the case of farmers over 40 years old an average area of their farms was 112.46 ha. Older farmers owned 3.5 times larger farms compared to representatives of the group of young farmers. Young farmers worked on their own, while the older farmers mostly employed hired workers. The modernization of farms was mainly financed by own capital, while all of them, without exception, used the available support for modernization of the farm. Due to the high costs of modernization of production, and above all the necessity to increase its scale by purchasing land, further development of farms run by young farmers will be slow, evolutionary, as was the case for farms run by farmers from the comparative group.
\end{abstract}

Key words: young farmers, modernization, farm

JEL code: Q12

\section{Introduction}

Poland is perceived as a country with great potential for agricultural production. The inclusion of Polish agriculture under the Common Agricultural Policy (CAP) favored and continues to support the processes of its restructuring and modernization (Stankiewicz 2010; Wozniak 2013; Sikora 2014). The possibility of benefiting from co-financing motivates farmers to modernize their farms, thus strengthening their market position (Dziwulski 2013; Tomczyk 2014).

However, in the opinion of many experts, despite the obvious impact of funds from the EU budget on investment opportunities of farms, the scale of impact of these funds on innovation and competitiveness of farms, especially those run by young farmers, has not yet been identified in detail. Although this situation is changing and there are new publications addressing this issue (including: Poczta 2013; Jozwiak, Zietara 2013; Young farmers'... 2015; Adamowicz, Szepeluk 2016; Rudnicki at al. 2017).

One of the strengths of Polish agriculture is young age of agricultural producers compared to other European countries. In Poland there are $14.7 \%$ of all farmers managing farms who are under the age of 35 , while in the EU-27 an average of $53.1 \%$ of farmers are people over 55 (23.5\% - in the range 55-64 years, $29.6 \%$ - over 65 years), and only $24.2 \%$ of owners are under the age of 44 ( $7.5 \%$ - under 35 years, $16.7 \%$ - in the range of 35-44 years) (Kania 2014). The age of the farmer is a factor that influences the production and economic results as well as the development potential of the farm (Rovný 2016; Rudnicki et al. 2017). However, it is difficult to specify the concept of young people / youth and characterize them strictly as a separate category among various other groups and social groups. Young farmers in the EU, under the CAP, are covered by special intervention policy instruments. According to the Regulation of the European Parliament and the EU Council No. $1307 / 2013$ of December 13, a young farmer is a person who has not exceeded 40 years

${ }^{1}$ Author: Tel.: +48 605850187; E-mail address: zbr@uwm.edu.pl 
of age and starts an agricultural activity or runs a farm for No more than 5 years. Generations of young farmers depend on the possibilities of further agricultural development, including ensuring the continuity of functioning of commercial farms.

Undoubtedly, strengthening the support for young farmers is justified by the greater potential of innovation and entrepreneurship of this group of farmers and their openness to innovation and understanding the need to solve environmental problems. As many researchers have noted, the support of this group of farmers allows to increase the dynamics of the agriculture modernization process and ensure long-lasting, stable development (Kania 2014; Mickiewicz, Mickiewicz 2015; Adamowicz, Szepelek 2016). However, the fundamental question is whether the implemented support mechanisms are effective in solving the problems of young farmers.

At a conference organized by the European Council of Young Farmers (CEJA) in Luxembourg in July 2015, a discussion was held on the prospects for agricultural policy and the main challenges regarding the development prospects of European agriculture were identified, including: increased social expectations towards agriculture (relating in particular to environmental protection, animal welfare, combating climate change) and increased demand for biomass. In 2015, CEJA adopted at the conference in Milan the so-called Young Farmer's Manifesto, which draws public attention to a number of key issues covered in the following areas:

- transition to a circular economy in order to reduce food waste and improve the functioning of the food chain; more fair treatment and protection of food producers,

- strengthening young farmers in the implementation of sustainable development and environmental protection,

- support in the use of innovative solutions that give the possibility of more production with less use of resources,

- enabling young farmers to create new jobs in rural areas and increase their share in building economic growth, including their share in trade (Young Farmer ... 2015).

An analysis of family farms shows that young farmers obtain better management results. This is evidenced by the productivity and profitability of all production factors, and especially the indicators referring to the use of labor resources (Needs of young ... 2014)

In Poland, young farmers have benefited from support for the start-up of the agricultural activity since 2004. This support is provided as part of the measure which can be generally referred to as a "Premium for young farmers" (the name of the measure differs in particular programming periods). It is also noteworthy that according to the Agency for Restructuring and Modernization of Agriculture (ARMA) data, in 20174112 people applied for 100000 grants for young farmers, which is almost $20 \%$ more applicants than in the previous year (3433 applicants). In view of the above, not only an assessment of the effects of the previously provided support but also the eligibility criteria are of importance (ARMA 2018).

The funds transferred under the CAP have an impact on the level of income from agricultural production (Lorencowicz, Cupial 2013). Although agriculture is an important link in the agribusiness sector, its share in favor of other sectors of the sector is gradually decreasing. At the same time, this decrease is compensated by the increase in efficiency, management effectiveness as well as the quality of production. The success of agricultural producers is most often defined by the ability to innovate, especially those of a technological and organizational nature (Vilkè et al. 2018). Young farmers are more open to new technical, technological or organizational solutions, and are more inclined to realize investments (Mickiewicz, Mickiewicz 2015). For this reason, young farmers are 
particularly supported by the EU by means of the Common Agricultural Policy instruments. This also applies to future agricultural policy 2021-2027.

It is young farmers from who efficient farm management is expected. The literature on the subject emphasizes that the succession of generations among farm managers contributes to the improvement of the quality of management processes (Lobley et al. 2010; Burton 2012; Dudek 2016; Czekaj 2016). Relatively young age and higher level of professional qualifications of farmers are conducive not only to modernization processes in farms (eg. introduction of innovations, intensification of investment activities), but also to improvement of economic results and environmental sustainability of agricultural activity (Wrzaszcz 2012).

In addition, young farmers are more open to changes in the environment. They can much more easily and more often than other farmers develop and diversify production, but also undertake nonagricultural activities (Meert et al. 2005). The production decisions taken, in turn, may affect not only the condition of farms, but also the economic situation of the rural population.

\section{Materials and Methods}

Research on the analysis of the development of farms managed by young farmers was carried out in 2018 in the Warminsko-Mazurskie Voivodeship. For comparative purposes, they included selected two groups of farmers, including 32 farmers meeting the EU criterion of "Young farmer" and 48 farmers aged over 40 . All research participants were covered by agricultural advisory service and managed highly commercial farms. The aim of the research was to answer the question whether young farmers who benefit from preferences under the Common Agricultural Policy are more willing than other farmers to modernize their farms. As research conducted in EU member states shows, a significant percentage of representatives of this group declares their activity regarding the modernization of their own farm (Young farmers' ... 2015). Investors are also willing to invest in old age farmers who run development farms. For this reason, a comparison was made between young and old age farmers managing farms recognized as development farms.

The farms were selected using a multi-stage sampling method, namely in the first stage a group of farmers managing highly commercial farms from the database of the European Farm Accountancy Data Network (FADN) have been selected for research, followed by a simple random sampling among units of economic size ( turnover in euros) above EUR 25,000, divided into two groups - those managed by young farmers and others. Advisers from the Warmian-Masurian Agricultural Advisory Centre conducted interviews with randomly selected farmers from both groups. The basic research tool was a research questionnaire.

\section{Results and Discussion \\ Characteristics of the research subjects' farms}

Observation of the condition of agriculture in the EU member states indicates that the decisive factor in the nature of production, despite the technological, organisational or biological progress being made, is the agricultural land. Large farms are able to introduce new technologies, improve the system of work organization, enter the food markets. There are in total 65101 farms in Warminsko-Mazurskie Voivodeship, including 64848 farms with crops. The average size of individual farms conducting agricultural activity is 18.40 ha. Against this background, the average area of farms young farmers participating in the study was 31.47 ha, while the area of farms run by other participants in the research, ie farmers over 40 years of age was 3.5 times higher and amounted to 112.46 on average. ha. 
In the Warminsko-Mazurskie Voivodeship, in 2013, a total of 59,833 full-time employees worked on the farm, while the total number of employees included the contribution of hired workers, casual employees, contractors and neighborly help. Out of all those employed in private farms the vast majority, as much as $85.7 \%$ was the family labor force (in Poland $91.2 \%$ ), while in farms participating in the research of young farmers, the family labor force accounted for $95.2 \%$, and in the comparative group - $794 \%$. The vast majority of research participants over 40 years of age employed hired workers using various forms of employment.

Animal production is another important area of analysis. Livestock includes: equines, cattle, pigs, sheep, goats, poultry, rabbits, fur animals, bee stumps and other animals kept on the farm for meat production. In the case of agricultural holdings operating in the voivodeship, farm animals were maintained in $53.8 \%$ of individual farms conducting agricultural activity. In this group, $67.14 \%$ of agricultural producers had cattle, and $34.7 \%$ owned pigs. The main production direction in the Warminsko-Mazurskie Voivodeship is plant production. In the case of the surveyed farms managed by young farmers, 4 out of 32 farms owned dairy cattle $(12.5 \%)$, beef cattle in 8 farms (including 2 that also deal with milk production), and another 2 farms of young farmers (12.5\%) specialized in sheep production. The remaining $62.5 \%$ of the farms of young farmers participating in the research specialized in crop production, mainly cultivating cereals and rapeseed. On the other hand, in the case of the group of older farmers covered by the research, who run a development farm, 4 out of the 48 farmers participating in the study were involved in the production of milk $(8.3 \%)$. There were three farmers in this group who also conducted cattle fattening. Another 3 farmers specialized in the production of pigs. $85.4 \%$ of representatives of this group of agricultural producers specialized in plant production. As it can be seen, farmers of old age withdrew from intensive animal production for much easier to manage plant production. As for the structure of crops, next to the production of cereals and rapeseed, a significant area was occupied by legumes and maize. Generally, owners of development farms much more often specialized in crop production than an average individual farmer from the territory of the Warminsko-Mazurskie Voivodeship.

While in the case of young farmers, none of them declared to have sources of income outside the farm, in the case of older farmers, non-agricultural activities were conducted by every fourth farmer. Non-agricultural activities related to the supply of agricultural products, services for agriculture and agricultural produce processing were thus related to the agribusiness sector.

\section{Sources and possibilities for modernization of development farms}

Young farmers who participated in the research were asked to assess the situation regarding the level of technical equipment of farms managed by them. The opinion that the current state of equipment is good, with farms needing further modernization, was expressed by $3 / 4$ representatives of this group of respondents. The others assessed the condition of their farms as unsatisfactory, however, declaring that they would undertake modernization activities in the future. Young farmers, who rated the level of technical equipment relatively low, owned the smallest farms (with an area from 14.8 ha to 26.0 ha). In the comparative group, which included farmers over 40, 38 respondents (79.2 \% of representatives of this group) considered that the current level of technical equipment of their farms is very high, and in their statements they declared that they are still looking for more innovative solutions. The remaining representatives of this group of farmers assessed the level of technical equipment of farms as high, and in the planned activities they will gradually complement the deficiencies in the equipment (Figure 1). Higher grades regarding the level of technical equipment 
of farms indicated by farmers aged over 40 are mainly correlated with a larger scale of production in these farms. As it can be seen, farmers, both young and older who managed commodity farms are characterized by a high propensity to undertake new investments.

The information obtained during the interviews allows to state that all young farmers participating in the research have benefited from EU support sources available for this group. Farmers representing the comparative group also in the past used the resources of the Rural Development Program aimed at modernization activities. Currently, the main source of financing new investments are mainly farmers' own funds and loans.

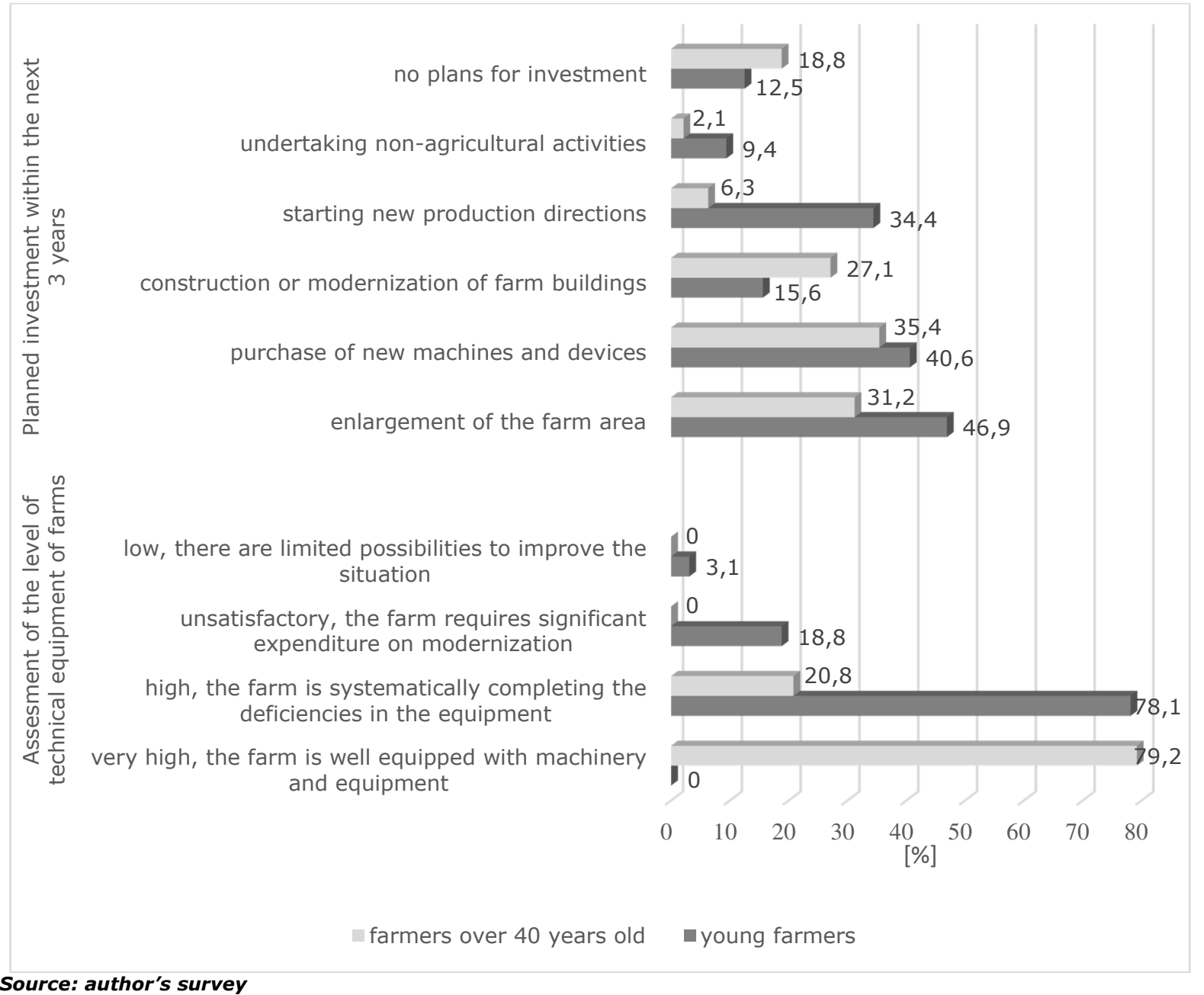

Source: author's survey

Fig. 1. Evaluation of farm equipment in technical equipment and planned investments in farms of the farmers covered by the research

Optimistic assessments, made by farmers, of the level of technical equipment of farms managed by them were verified by asking them about planned investments within the next 3 years, which may contribute to the improvement of management efficiency. The statements of the research participants, especially young farmers, show that one of the basic conditions for increasing the efficiency of farming is enlarging the farm area. Such plans within the next 3 years were declared by every second young farmer (46.9\%) and every third farmer from the comparative group $(31.2 \%)$. The next plans indicated by the research participants concerned the purchase of new machines and devices, which were declared by $40.6 \%$ of young farmers and $35.4 \%$ of farmers in the comparative group respectively. $27.1 \%$ of farmers aged over 40 and $15.6 \%$ of young farmers planned to build or modernize their farm buildings. Young farmers were interested more often than others in starting new production lines (including, among others, vegetable growing, growing energy crops, etc.). It 
was noted that $12.5 \%$ of young farmers and $18.8 \%$ of the remaining respondents did not intend to invest in the modernization of their own farm in the coming years. It is significant that a small percentage of a young farmers, however, almost three times higher than in the group of farmers over 40 years of age, included non-agricultural activities in their potential decisions regarding modernization of (Figure 1). It should be noted, that during the time of the research, every fourth farmer aged over 40 had already conducted non-agricultural activities, while in the group of young farmers there were No such people.

One of the main barriers to the modernization of farms run by young farmers turned out to be the high costs of necessary investments, as well as the current financial situation (repayment of outstanding loans, relatively low revenues). For these reasons, even when obtaining subsequent tranches of support from the EU budget, the development of farms run by young farmers will be of an evolutionary nature, similarly as it was in the past in the case of farms run by farmers from the comparative group. As it was observed, one of the basic barriers limiting the further development of farms run by young farmers is the relatively small farm area (about 2 times bigger than the average area of individual farms in the region and 3.5 times smaller than the average area of farms run by farmers after 40). Agricultural land takeover by young farmers is constricted by the lack of appropriate national support mechanisms. There were frequent instances of informal, and therefore not included in the presented research results, land rent by young farmers. This phenomenon means that the agricultural land area owner receives subsidies, while the young farmer uses the land without paying the rent. In such cases, the young farmer does not show the actual area on which he runs agricultural activity, which makes it difficult, for example, to obtain a loan for the purchase of machinery and equipment.

Research participants aged over 40, when asked to indicate the main barrier to farm modernization, mostly pointed to the instability of prices for agricultural products ( $91.7 \%)$. As it can be seen, the two compared groups of farmers are characterized by a significant difference regarding both the current economic situation of farms and priorities.

\section{Conclusions}

Agriculture is an important sector of economic activity of the inhabitants of the WarminskoMazurskie Voivodeship. The economic and social significance of agriculture has always been strategic in this region of Poland, not only because of the place and nature of the work, but also its role in the rural space and its strong impact on other types of economic activity of the inhabitants. The favorable agrarian structure, compared to other provinces in the country, and the concentration of production in larger farms in terms of area favors the commodity character of production.

Research shows that young farmers are gradually raising the level of technical equipment of their farms. The most frequently investments indicated as priority include land purchase, purchase of new machines and equipment, and new production directions. Investment in the modernization of production technologies, which can contribute to strengthening the position of agricultural producers in the food supply chain, should be considered the most effective. All farmers participating in the research (both young and the remaining) were willing to use every available opportunity to obtain external financial support.

Due to the limited access to financing sources, there is a need to introduce additional support mechanisms for the development of commercial farms run by young farmers. This support may be of a non-financial nature and may include, inter alia, undertaking counseling activities to improve 
management efficiency, organization and planning of production in order to encourage farmers to cooperate. The effectiveness of the solutions indicated here depends, however, on the involvement of farmers, their need for action, ingenuity and diligence.

Observation of the situation in both Polish and European agriculture allows to conclude that the main character of the farms owned by young farmers is mainly determined by the available land resources. Bigger farms in terms of area are able to introduce modern technologies, improve work organization, enter new markets.

Due to the fact that young farmers are becoming one of the strategic groups of functioning and development of the whole agribusiness sector, supporting them has a positive impact both on the multifunctional development of rural areas and on the social situation of the rural population.

\section{Acknowledgements}

Data for this research was collected during the implementation of scientific research project funded by a grant (No. 22.660.003-300) from the National Centre for Agricultural Support, Olsztyn, Poland.

\section{Bibliography}

1. Adamowicz M. Szepeluk A. (2016). Support to Young Farmers as Part of Agricultural Policy of the European Union. Zagadnienia Ekonomiki Rolnej, 3(348), 106-128. DOI: 10.5604/00441600.1218186.

2. Burton R., Fischer H. (2015). The succession crisis in European Agriculture. Sociologia Ruralis, Vol. 55, No 2, 155-166.

3. Czekaj M. (2016). Selected problems of succesion of farms in Poland. Prace Naukowe Uniwersytetu Ekonomicznego we Wrocławiu, 439, 77-89.

4. Dudek M. (2016). The succession of individual farms as a factor of structural transformation in Polish agriculture. Studia i Monografie 170, IERiGŻ-PIB, Warszawa, pp. 177.

5. Dziwulski M. (2013). Investment Activity of Polish Agricultural Holdings in 2010 in Terms of their Economic Size. Zesz. Nauk. Uniw. Szczec. Finanse. Rynki finansowe. Ubezpieczenia, 59, 481-490.

6. Felczak T. (2014). The impact of the economic size and farming type of agricultural farms on nature of liquidity strategy. Zeszyty Naukowe Uniwersytetu Szczecińskiego nr 804, Finanse, Rynki Finansowe, Ubezpieczenia, No 67, 201-210; www. wneiz.pl/frfu.

7. Jozwiak, W., Zietara, W. (2013). Kierunki i zakres wsparcia inwestycji w polskich gospodarstwach rolnych $w$ latach 2014-2020. [Directions and scope of investment support in Polish farms in 2014-2020]. Zagadnienia Ekonomiki Rolnej, nr 1(334), 42-58.

8. Kania J. (2014). Young farmers in family farms of the European Union. Problems of Small Agricultural Holdings, No. 3, 35-50.

9. Lobley M., Baker J.R., Witehead I. (2010). Farm succession and retirement: some international comparisons. Journal of Agriculture, Food Systems and Community Development, vol 1(1), 55-64.

10. Lorencowicz E., Cupial M. (2013). Assessment of investing activity of farmers using the EU funds on the example of Lubelskie Voivodeship. ACTA Sci. Pol., Oeconomia, 12(1), 19-24.

11. Meert H., Van Huylenbroeck G., Vernimmen T., Bourgeois M., van Hecke E. (2005). Farm household survival and diversification on marginal farms. Journal of Rural Studies, 21, 81-97.

12. Mickiewicz A. Mickiewicz B. (2015). The process of supporting Young farmers in Polish agriculture. Problems of Small Agricultural Holdings, 3, 67-81.

13. Needs of young farmers. Report I of the Pilot project: Exchange programmes for young farmers Final. (2015). European Commission, Directorate-General for Agriculture and Rural Development, Brussels.

14. Poczta W. (2013). Agricultural holdings in Poland against the background of EU farms - the impact of the CAP. Powszechny Spis Rolny 2010, GUS, Warszawa.

15. Rovný P. (2016). The analysis of farm population with respect to young farmers in the European Union. Procedia - Social and Behavioral Sciences 220, 391-398.

16. Rudnicki R., Dubownik A., Szyda B. (2017). European Union Support for Young Farmers and Managers of Agricultural Holdings Age Structure in Poland. Komitet Przestrzennego Zagospodarowania Kraju PAN, No 267, 50-69.

17. Sikora J. (2014). The modernization of polish farms assisted with the EU Funds under measure 121. of Rural Development Programme 2007-2013. Roczniki Naukowe SERiA, t. 16, z. 6, 438-443.

18. Stankiewicz D. (2010). Impact of EU Accession on Modernization of Polish Agricultur. Studia BAS, No 4(24), 217-245.

19. Tomczyk A. (2014). Technical modernization in the farm south Poland. Acta Sci. Pol., Technica Agraria, $13(1-2), 49-55$. 
20. Vilkè R., Vidickienè D., Gedminaitè-Raudonè Z. (2018). Innovating apart of together: Lithuanian farmers and rural communities. Research for Rural Development 2018, vol. 2, 160-166, DOI: 10.22616/rrd.24.2018.067.

21. Wozniak M.G. (2013). External Conditions of Modernization of Polish Economy and Socio-Economic Cohesion. Wyd. Uniwersytetu Rzeszowskiego, No 30, 71-89.

22. Wrzaszcz W. (2012). The Sustainability of Individual Holdings in Poland on the Basis of FADN Data. Studia i Monografie 155, IERiGŻ-PIB, Warszawa.

23. Young Farmer Manifesto Ceja. (2015). The European Council of Young Farmers, 2015. 